\title{
EXPRESSING PROPERTY CONCEPTS IN LETEH ${ }^{1}$ (LARTEH)
}

\author{
Mercy Akrofi-Ansah
}

\begin{abstract}
Languages have diverse strategies for expressing property concepts. This paper discusses various ways by which property concepts are communicated in Leteh (Kwa: Niger-Congo). In Leteh, property concepts are indicated by the use of a small class of adjectives, made up of thirteen monomorphemic members. The thirteen members represent semantic classes of dimension, age, color and value. In addition to the small class of adjectives, some nouns and verbs in various forms are also used to describe property concepts which denote physical and human attributes. Nouns which are used to designate property concepts may be put under three groups: nominal adjectives, noun modifiers, and noun reduplicatives. There is a special class of intransitive verbs which may be used to describe property concepts. It has been observed that these intransitive verbs are synonymous to some members of the adjective class. Furthermore, there is a set of verbs which make use of the 'have' verb: bò followed by an abstract noun to signify human propensity. Finally, relative clauses are employed as modifiers where the relativizer né introduces the property concept. Data for the study is from a Leteh corpus built by the author. The study contributes to the ongoing debate on the typology of adjective classes.

KEY WORDS: Leteh; noun modifiers; adjectives; noun reduplicatives; relative clause.

\section{RÉSUMÉ}

Les langues passent par diverses stratégies pour exprimer des concepts de propriété. Ce document passe en revue les différentes façons par lesquelles se fait la communication des notions de propriété en dialecte Leteh (Kwa: Niger-Congo). En dialecte Leteh, les concepts de propriété sont indiqués par l'utilisation d'une catégorie restreinte d'adjectifs composée de treize membres mono-morphémiques. Ces treize membres représentent les catégories sémantiques suivantes : dimension, âge, couleur et valeur. En plus de la catégorie restreinte d'adjectifs, certains noms et verbes sous différentes
\end{abstract}

\footnotetext{
${ }^{1}$ The name of the language under discussion is known by its speakers as Let $\varepsilon$; in the literature and elsewhere, it is spelt as Larteh which is synonymous to the name of the town where the language is spoken. However in this paper, the spelling adopted is Leteh, for ease of electronic accessibility.
} 
formes sont utilisés pour décrire des attributs physiques et humains. Les substantifs dont l'utilisation désigne les concepts de propriété peuvent se classifier en trois groupes: adjectifs nominaux, modificateurs de nom, et réduplicatifs nominaux. Il existe une catégorie spéciale de verbes intransitifs. Ces derniers peuvent être utilisés pour décrire des concepts de propriété. Un constat a été fait selon lequel ces verbes intransitifs sont synonymes de certains membres de la catégorie d'adjectifs. En outre, il existe un ensemble de verbes qui font usage du verbe «avoir »: bò suivi d'un nom abstrait pour signifier la propension humaine. Enfin, les propositions relatives sont utilisées comme modificateurs dans les cas où cas le relativisateur né introduit la notion de propriété. Les données de l'étude sont issues d'un corpus en dialecte Leteh créé par l'auteur. L'étude joue son rôle dans les discussions actuels sur la typologie des catégories d'adjectifs.

http://dx.doi.org/10.4314/gil.v2i2.2

\section{Introduction}

\subsection{The Adjective Class}

Linguistic literature is rife with discussions on the adjective class in the world's languages. This paper seeks to contribute to the discussion on the typology of adjective classes by describing the range of linguistic devices used in Leteh to describe property concepts. Issues related to the adjective class which have sparked off debate in the literature include its universality, nature and size (see Backhouse 1984; Madugu 1976; Omoruyi 1986; Dixon 1977, 1982, 2004; Osam 1999, 2003; Dakubu 2003; Dorvlo 2009). Linguists have also been interested in investigating how languages with few adjectives denote property concepts which the few adjectives are not able to express (see Ameka 1991, 2003 concerning Ewe).

One way by which linguists have tried to confirm the existence of the adjective class in a particular language has been to try to distinguish it from verbs and nouns. This approach is based on the assumption that each word class possesses unique grammatical properties (Schachter and Shopen 2007). For example, in many of the world's languages, it is only verbs which are known to inflect for tense and aspect. Nouns on the other hand have been found to share a number of morphosyntactic properties with adjectives. Nevertheless, Dixon (2010) proposes further tests which could help to differentiate between nouns and adjectives, for instance, the function of adjectives as parameters in comparative construction seems to be exclusive to adjectives. 
Furthermore, languages differ with regard to the size of adjective classes. Whilst some languages, like the European languages have large and open class membership, others like Igbo, Yoruba and Ewe have small closed adjective classes, numbering less than ten members (Dixon 2004; Ameka 1991, 2003).

It is further noted that regardless of the size of the adjective class of a language, members of the class usually represent four core semantic types: dimension, age, value and color. In addition to these, medium and larger classes may include semantic types of human propensity, physical property and speed (Dixon 2004).

\subsection{The Adjective Class in some Kwa Languages}

This section gives an overview of the nature of the adjective class in selected Kwa languages: Akan, Ga, Ewe and Logba. Osam (1999, 2003) and Amfo, Boateng and Otoo (2007) discuss the nature of the Akan adjective class. Although these do not report on the exact number of adjectives that Akan possesses, the discussions indicate that Akan makes use of both underived adjectives (deep level adjectives) and derived ones which originate from verbs and nouns. It is detected however that, Akan adjectives that develop from nouns outnumber those derived from verbs (Osam 1999).

Similar to the underived Akan adjective class, that of $\mathrm{Ga}$ is also small. Derivational processes that Akan and $\mathrm{Ga}$ undergo to generate adjectives from verbs and nouns are alike, for instance, the two languages utilize suffixation to derive adjectives from verbs. Furthermore, a class of derived adjectives which Osam (1999) describes as 'adjectival verbs', characterized by verb-adjective symmetries are said to be present in both Akan and Ga, but absent in Ewe (Amfo, Boateng and Otoo 2007).

With regard to Ewe, Ameka (1991, 2003) identifies five underived adjectives, and a large class made up of derived adjectives of nouns and verbs origin. In comparison with Akan and Ga, Ewe is known to have more derivational processes that produce adjectives. The processes include suffixation, reduplication, compounding of verbs and their complements and compounding of clauses and clausal parts. Furthermore, Ameka (2003) reports of a peculiar class of adjectives whose source has not yet been identified. He however suggests that those adjectives may have been historically derived.

In answering the question as to whether Logba (Kwa) has an adjective class, Dorvlo (2009) argues for its existence in the language. According to Dorvlo (2009), Logba has only one non-derived adjective which connotes the meaning of 'value'. Other lexical words for descriptive purposes are formed through suffixation of verbs, reduplication of nouns, and the compounding of an intransitive verb root and a noun. In Logba, ideophones are used as qualifiers of nouns. It is interesting to note that adjectives in Logba are only used attributively. 
The discussion so far has pointed out some similarities that underived adjective classes of some Kwa languages, including Leteh have in common. The most striking common feature is their small sizes. In the case of derived adjectives, they are noted to be of verbal and nominal origins. However, in some instances, there is evidence that derivational processes that produce adjectives in Kwa languages differ. The present paper for example, will demonstrate that in Leteh, the only derivational process which yields lexemes that describe property concepts is reduplication of some mass nouns. In addition, nouns and verbs in various forms are employed to convey other property concepts that indicate physical and human attributes.

The discussion will proceed as follows: section 2 dwells on some grammatical features of Leteh which are relevant to the present discussion. Section 3 pays attention to the Leteh adjective class and the morphosyntactic properties of its members. In section 4, other means of connoting property concepts in Leteh are described. The function of these expressions will also be demonstrated. In section 5, the order of adjectives in the Leteh simple noun phrase will be dealt with. Section 6 summarizes and concludes the paper.

\subsection{Some Grammatical Features of Leteh}

In this section, I present the Leteh language and some grammatical features which will be useful to this discussion. Lewis (2009) sub-classifies Guan (Kwa, NigerCongo) into two language clusters: North Guan and South Guan. Leteh, the language under discussion, is a member of the South Guan group. The language is spoken by about 8,310 people (Ghana Housing and Population Census, 2000) in Larteh, a town located in the South-eastern part of Ghana, West Africa.

\subsection{Leteh Basic Constituent Order}

The study of word order typology has attracted linguists' attention, because studies have shown that the order of the three core constituents of a clause: Subject (S), Verb $(\mathrm{V})$, Object $(\mathrm{O})$, has implications for the ordering of some pairs of elements at other syntactic levels (Dryer 2007).

Like many African languages, Leteh has a basic constituent order that is fixed: the subject and object occur in a fixed position in relation to the verb in the basic word order. The unmarked clause (1) exemplifies the basic constituent order of Leteh, which is SVO. 


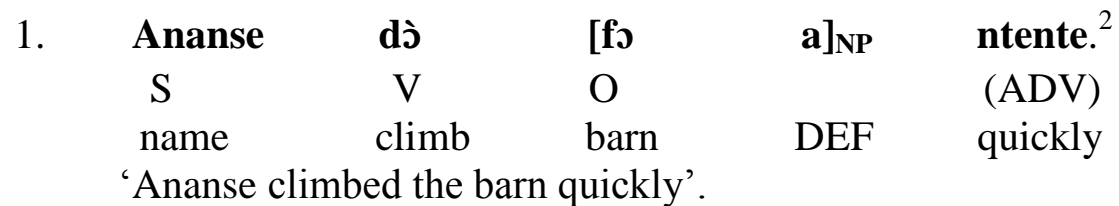

In (1), the subject is a lexical word (a proper name), followed directly by a verb. The object, a noun phrase, consists of a lexical word and an article. In a simple transitive clause such as (1), the subject, verb and object are obligatory constituents. The adverbial occurs as an optional element in the clause. Adverbials may be temporal, locative or describe manner as in (1)) and their position is clause-final with the exception of temporal adverbials which can also occupy the clause-initial position (Akrofi Ansah 2009).

\subsection{The Structure of the Leteh Simple Noun Phrase}

The Leteh noun phrase in the simplest form can be constituted by a lexical noun (2) or a pronoun (3). Whilst the lexical noun may occur with modifiers, the pronoun is not modified. The internal structure of a simple NP where the head noun is modified may be represented as in (4).

2. o-tse

SG-woman

woman

3. wone

2PL

4. $\quad \mathrm{NP} \rightarrow \mathrm{N}(\mathrm{ADJ})(\mathrm{QT} / \mathrm{NUM})(\mathrm{DET})$

The head noun is the obligatory element, and it may be modified by an adjective, a quantifier, a numeral and determiners in the form of an article (definite and indefinite) or a demonstrative. In the noun phrase, the adjective follows the noun directly, and it may also be followed by a quantifier or a numeral and then finally by one determiner. The order of the elements in the NP is exemplified in (5b).

5a. [O-tse o-kpomkpo a $]_{\mathrm{NP}}$

SG-woman SG-big DEF

'The fat woman'.

\footnotetext{
${ }^{2}$ Verbs are tone-marked to make tense/aspectual distinctions.
} 


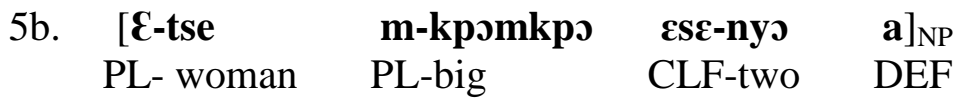

'The two fat women'.

Examples (5a) and (5b) further demonstrate that there is number agreement between the adjective and the noun.

\subsection{Structure of the Leteh Relative Clause}

In Leteh, what marks a relative clause is a clause-initial né. This is similar to Ewe (Ameka, 1991) and Akan (Schachter and Shopen, 2007) where it is relativizers that are used to mark relative clauses. According to Dryer (2007: 96), "Almost all VO languages place the relative clause after the noun... ." The ordering of the adjective and the noun (N, ADJ) in a Leteh simple NP is the same as that of a relative clause and the head noun (N, RELC). Generally, relative clauses “...carry information that a speaker wants an addressee to assume in order for him/her to process the rest of the discourse more easily" (Ameka 1991: 275). In addition to this function, a Leteh relative clause may be used to modify the head of a noun phrase as exemplified in (6). It may also be used to modify a direct object (7). In both instances, the relative clause which modifies the subject NP and the direct object occurs directly after them correspondingly.
6. Akutu [né bo ofa $]_{\text {RELC }}$
orange REL has sweetness
'sweet orange(s)'.
7. Ama wòr ̀̀ n-ataale [né bo oni $]_{\text {RELC }}$
Name PRES.wear PL-dress REL has hardness
'Ama wears expensive dresses.

\subsection{Leteh Comparative Constructions}

It is attested that there is some correlation between the order of verb, object in a clause, and that of elements in a comparative construction. It is expected that the order of elements in a comparative construction in VO languages should be: marker of comparison; standard of comparison (Dryer 2007). Leteh expresses comparison through a grammaticalized comparative construction where the elements are the known standard against which the subject of the clause is compared; the marker nyà 'exceed/surpass' that signals a comparative construction, and the quality or parameter, usually a predicative adjective (8) or its adjectival verb equivalent (9) (see section 4.) by which the subject is compared with the standard.

The structure of a Leteh comparative construction is illustrated in (8) and (9). 
8. Afi gyí otonto nyà Ama.

OC COP.be long/tall exceed/surpass SC

'Afi is taller than Ama.'

$\begin{array}{lll}\text { 9. Afi kpa nyà } & \text { Ama. } \\ \text { OC long/tall exceed/surpass } & \text { SC } \\ \text { 'Kofi is taller than Ama.' } & \end{array}$

\subsection{Underived Adjectives}

The Leteh adjective class is constituted by thirteen monomorphemic lexemes (table 1) which do not originate from any word class. It is noteworthy that all the adjectives have vowel prefixes. The thirteen adjectives span the four core semantic types put forward by Dixon (1982).With the exception of the semantic class of color, each semantic class exhibits at least, one antonymic pair. Within the semantic class of value for instance, the antonymic pairs are good/bad; true/false.

TABLE 1

\begin{tabular}{|c|c|c|c|}
\hline DIMENSION & COLOR & AGE & VALUE \\
\hline 'short' & ofufuru 'white' & ohue 'new' & 'good' \\
\hline otonts & obibi 'black' & odede 'old' & okpamkpa 'bad' \\
\hline akitibi & 'red' & & 'true' \\
\hline okpomkpo 'big' & & & enufu \\
\hline
\end{tabular}

\subsection{Morphosyntactic Properties of Underived Adjectives}

As already stated, the underived adjectives are monomorphemic words with vowel prefixes. The adjectives, with the exception of adjectives of value (11) agree in number with the nouns they modify which results in a change of their prefixes, from singular to plural prefixes (10).

$\begin{array}{ll}\begin{array}{l}\text { 10. a-yirebi a-timi } \\ \text { SG-child SG-short }\end{array} & \begin{array}{l}\text { n-yirebi n-timi } \\ \text { PL-child PL-short } \\ \text { 'short children' }\end{array} \\ \text { 'short child' } & \\ & \text { n-yirebi okose } \\ \text { 11. a-yirebi okose } & \text { PL-child good } \\ \text { SG-child good } & \text { 'good children' }\end{array}$


Furthermore, all Leteh underived adjectives with the exception of adjectives of value undergo complete reduplication $(12 \mathrm{a}-\mathrm{c})$. It must be noted that for the adjectives to be reduplicated, they must be in the plural form which explains why adjectives of value do not undergo reduplication (12d). In Leteh, reduplicated adjectives signify intensity and may be used to modify plural nouns (13). Although nouns may also be reduplicated, their category changes to adjectives when they undergo reduplication (see section 4. 2).

Basic form

12a. o-tonts;

b. o-fufuru; e-fufuru

c. o-hue;

*d. okose;

\section{e-hue}

okose
Reduplicated form

ntontontonts

efufuruefufuru

ehuehue

*okoscokose

\section{N-yirebi ntontontonts a.}

PL-child tall-tall DEF

'The very tall children.'

Syntactically, all underived adjectives possess attributive functions (14 \& 15).

\section{Ama bèsś a-tale o-hue.}

Name FUT-buy SG-dress SG-new

'Ama will buy a new dress.'

\section{Kofi bò tsa o-kpomkpo.}

Name has house SG-big

'Kofi has a big house.'

Apart from value adjectives, the remaining underived adjectives may be used predicatively. In their predicative function, they are preceded by the copula gyí, 'be' (16). As already stated, value adjectives are not used predicatively; the sentence of

(17) is therefore unacceptable.

16. Atale a gyí odede. dress DEF COP.be old 'The dress is old.'

17. *Ayirebi a gyí okpamkpa child DEF COP.be bad 'The child is bad.' 
One syntactic function that underived adjectives share with nouns is their role as heads of a simple noun phrase. In (18), the adjective is used attributively, and in (19), its function as head of the noun phrase: $\mathbf{s h} \boldsymbol{\varepsilon} \mathbf{a}$ 'the red one' is illustrated.

\section{Owure ohe a yé-sútè. book red DEF PERF-burnt}

'The red book is burnt.'

19. Jhe a yé-sútè.

red DEF PERF-burn

'The red (one) is burnt.'

The use of an underived adjective as head of a noun phrase is restricted to interactions where participants have previous knowledge of subject matter. The statement in (19) will therefore not make sense to someone who was not a participant in a previous conversation.

Finally, on the syntactic properties of underived adjectives in Leteh, the latter function to express comparative degree. This is done by the use of a verb nyà which translates as 'exceed/surpass'. In expressing comparative degree, the Leteh speaker has a choice of using a predicative adjective (20) or its verbal counterpart (21) (refer to section 4.). The phenomenon is also attested in some Kwa languages (Amfo, Boateng and Otoo (2007: 69).

$\begin{array}{clll}\text { 20. Kofi gyí } \quad \text { okpomkpo nyà } & \text { Ama. } \\ \text { OC COP.be big } & \text { surpass/exceed } & \text { SC } \\ \text { 'Kofi is bigger than Ama.' } & & \end{array}$
21. Kofi dè nyà Ama.
OC big surpass/exceed SC
'Kofi is bigger than Ama.'

\subsection{Using Nouns and Verbs to Communicate Property Concepts}

Nouns and verbs in various forms may be used to convey property concepts in Leteh. In Leteh, it has been observed that human propensity and physical properties are largely connoted by these nouns and verbs.

\subsection{Nominal Adjectives}

In Leteh, nouns which receive agentive markers: o-/o- as prefixes and the suffix -wo (22) and (23) can be used as modifiers to express property concepts of other nouns. These function attributively, occurring after the head noun (24) and (25). 
22. $\varepsilon$ tro $\rightarrow$ o-tro-wo

madness 'mad person'

23. enufu $\rightarrow$ o-nufu-wo

lie 'dishonest person'

24a. o-nyine o-trowo

SG-man SG-mad person

'mad man'

25a. a-yirebi o-nufuwo

SG-child SG-dishonest person

'dishonest child'

\author{
24b. e-nyine $\varepsilon$-trowo \\ PL-man PL-mad person \\ 'mad men'
}

25b. n-yirebi e-nufuwo

PL-child PL-dishonest person

'dishonest children'

These nominal adjectives are mostly used to connote human propensity, and may be pluralized to agree with the nouns they modify (24b) and (25b).

\subsection{Noun Modifiers}

These are nouns which denote some substance or material (26a-c), and are usually used to express physical attributes of nouns. Noun modifiers are not marked for plural (27), and do not undergo reduplication.

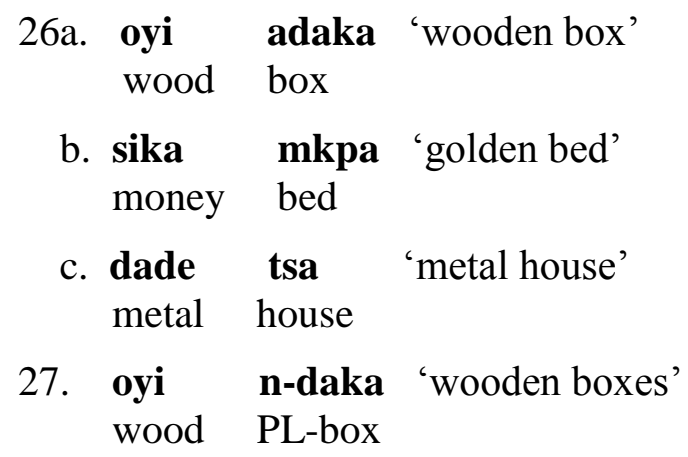

From examples (26) and (27), it is clear that noun modifiers precede the nouns they modify, an order which is contrary to Leteh noun phrase order. Noun modifiers are used attributively (28), and also as predicates in ascriptive clauses to attribute a property to a noun (29).

\section{Sika mkpa a yé-fé.}

Money bed DEF PERF-lose

'The golden bed is missing.' 
29. Tsa mo gyí oyi.

house DEM COP.be wood

'This house is wooden.'

\subsection{Noun Reduplicatives}

There is a class of nouns, largely mass nouns which undergo total reduplication $(30 \mathrm{a}-\mathrm{c})$ to function as adjectives. This morphological behavior of nouns is one of the few features that differentiates adjectives from nouns. Unlike nouns which change their category when they are reduplicated, adjective stems denote plurality when they undergo reduplication. Noun reduplicatives usually signify physical property.

$\begin{array}{rll}\text { Basic form } & & \text { Reduplicated form } \\ \text { 30a. ntsu 'water' } \rightarrow & \text { ntsuntsu 'watery' } \\ \text { b. ebi 'seed' } \rightarrow & \text { ebiebi 'lumpy' } \\ \text { c. mfra 'salt' } \rightarrow & \text { mframfra 'salty' }\end{array}$

Noun reduplicatives do not inflect for number. They are used attributively and predicatively to modify other mass nouns $(31 \& 32)$.
31. Tegyi mframfra a yé-té.
food salty DEF PERF-finish
'The salty food is finished.'
32. Otsu a gyí ntsuntsu.
soup DEF COP.be watery
'The soup is watery.'

\subsection{Adjectival Verbs}

In Leteh, verbs which are used to express adjectival meaning may be put into two groups. In the first group, we have some verbs which are synonymous to some underived adjectives and function like intransitive verbs (33a-c). These adjectival verbs occur immediately after a noun phrase to communicate adjectival meaning (34 \& 35).

underived adjective
33a. skpamkpa 'bad'
b. okpэmkpo 'big'
c. otonts
'tall'

adjectival verbs

maane 'to be bad'

de 'to be big'

kpa 'to be tall' 
34. Tsa mo de.

house DEM de

'This house (is) big.'

35. Ayirebi a maane.

child DEF bad

'The child (is) bad.'

These lexemes can be appropriately described as verbal, because they exhibit verbal features; for instance, they inflect for negation (36).

\section{Tsa mo bé-de. \\ house DEM NEG-big \\ 'This house is not big.'}

\subsection{Using the 'have' Verb bò to Express Property Concepts}

The second strategy of using verbs to indicate property concepts is by using the 'have' verb, bò, followed by an abstract noun. In this construction, the noun is said to possess the quality expressed by the abstract noun $(37 \& 38)$. These structures are usually used to indicate physical property.

\section{Agbeli bò oni.}

cassava have hardness

'Cassava is expensive.'

\section{Olu a bò oketa. \\ medicine DEF has bitterness \\ 'The medicine is bitter.'}

Similar to the verbal adjective, the 'have' verb bò can receive negation in the form of a homorganic negative prefix (39). In this construction, the opposite quality is implied as in (40). It is important to note that the tone of the have verb changes from low to high when it is negated.

39. Olu a m-bó sketa medicine DEF NEG-have bitterness

'The medicine is not bitter.'

40. Olu a bò ofa

medicine DEF have sweetness

'The medicine is sweet.' 


\subsection{The Relative Clause as Modifier}

The relative clause in Leteh may be used to modify the head of a noun phrase. The clause is introduced by the relativizer né and followed by the perfect marker yé-/yé-, and then a verb which connotes physical attribute. In (41) for example, the verb signifies the action (ripening) that the orange underwent to attain the physical property (ripe). In (41\&42), the relative clauses describe the physical states of the 'orange' and the 'piece of cloth'.

\section{Akutu [né yé-hènè] \\ orange REL PERF-ripe \\ 'orange which is ripe/ ripened orange'}

\section{Eta [né yé-hòrè] \\ cloth REL PERF-wet \\ 'cloth which is wet/wet cloth'}

\subsection{Ordering Multiple Adjectives in a Leteh Noun Phrase}

The issue of adjective sequencing restrictions (henceforth, ASR) is one that has been widely discussed in the literature. Ameka (1991: 113) reports that in Ewe, age items occur first in a sequence, and attributes it to the importance speakers of Ewe attach to age. In the case of Siya (Kwa) also, adjectives which connote age occur closest to the noun they modify, after which others may follow. Adjei (2007) further notes that in Siya, after placing the age adjective first, stringing the remaining adjectives is at the discretion of speakers to a large extent. In the case of Akan, a preliminary investigation on ASR conducted by Pokuaa, Osam and Saah (2007) found that age and color adjectives occur closest to the noun they modify. It was also observed that for Akan, human propensity adjectives largely occur farther away from the head noun.

The discussion on adjective sequencing in Leteh will account both for the case of adjectives from different semantic classes, and adjectives from the same semantic class. It must be noted that both underived adjectives and other nominal and verbal expressions which are employed to signify property concepts can occur in a sequence.

In order to get the correct or most preferred sequences, various adjective orderings were presented to Leteh speakers, and in most of the cases, speakers showed a large measure of agreement on the ensuing orderings.

From examples (43)-(45), we see the order of Leteh adjectives from different semantic classes in a noun phrase.
43. o-nyine
o-kpamkpa
o-tonto
a 
SG-man SG-bad SG-tall DEF

'The bad tall man'

There are two adjectives in (43), modifying the head noun onyine 'man'. The adjective denoting value precedes that signaling dimension. The order can be represented as: VALUE>DIMENSION. Speakers explained that the character of an individual was more important than his looks, which explains why the value adjective occurs closest to the head noun.

Example (44) demonstrates the adjectival order: VALUE>DIMENSION $>$ COLOUR. In this case, color occurs last, which gives an indication that speakers do not attach much importance to the physical attributes of an individual. This order also follows what Sproat and Shih (1991) and Dixon (1977) posited for many of the world's languages.

\section{4. o-nyine o-kpamkpa o-tonto ohe a \\ SG-man SG-bad SG-tall red DEF \\ 'The bad tall fair man'}

In (45), the four adjectives that modify the noun occur in the order: AGE $>$ VALUE $>$ DIMENSION $>$ COLOUR. This order is similar to what pertains in related languages like Akan and Ewe (Pokuaa, Osam and Saah 2007; Ameka 1991) where age adjectives are placed closest to the nouns they modify. The tendency to place age adjectives closest to head nouns seems to be cross-cultural. The explanation offered by Ameka (1991) goes for Leteh as well. Among the speakers of Leteh, the age of an individual is an overriding consideration in any interaction. The age of participants in a conversation will determine address forms and choice of words of speakers in most cases.

\section{5. o-nyine o-numu o-kpamkpa o-tonts ohe a \\ SG-man SG-old SG-bad SG-tall red DEF \\ 'The old bad tall fair man'}

During an interaction, a speaker would normally use a sequence of adjectives to specify a referent to ensure that the addressee makes no mistake in identifying the referent. When an adult is sending a child on an errand to deliver a message for instance, to ensure that the message is sent to the right person, the adult would use a string of adjectives to describe the intended recipient.

On the other hand, multiple adjectives that occur as modifiers could come from the same semantic class. When that occurs, the order remains the prerogative of the speaker; normally depending on ease of producing them, and also which of the adjectives the speaker wants to emphasize (Bybee 1985). In many cases, the adjective 
the speaker wants to emphasize is put closest to the head (see examples (46) and (47)).

$$
\begin{array}{llll}
\text { o-yi } & \text { o-kpomkpo } & \text { o-tonts } & \text { o-ko } \\
\text { SG-tree } & \text { SG-big } & \text { SG-tall } & \text { SG- a/some } \\
\text { 'A big tall tree.' } & &
\end{array}
$$

$\begin{array}{llll}\text { o-yi } & \text { o-tonts } & \text { o-kpomkpo } & \text { o-ko } \\ \text { SG-tree } & \text { SG-tall } & \text { SG-big } & \text { SG-a/some } \\ \text { 'A tall big tree.' } & & \end{array}$

My informants however preferred option (47); they explained that it was easier to produce o-tonts 'tall' than o-kpomkpo 'big'. In the instance where adjectives come from the same semantic class, speakers would also prefer to produce the morphologically simpler adjective first. Consequently, phrases and clauses which are used to signify property notions are usually placed last in the series (48).

$\begin{array}{llllll}\text { (48) Koko } & \text { ofufuru } & \text { ntsuntsu } & \text { [né } & \text { bo } & \text { ofa]. } \\ \text { porridge } & \text { white } & \text { watery } & \text { REL } & \text { have } & \text { sweetness } \\ \text { 'White watery sweet porridge.' } & & & \end{array}$

\subsection{Conclusion}

The paper has discussed strategies that Leteh employs to express property concepts. The language makes use of underived adjectives (a class of thirteen monomorphemic lexemes) and derived ones, mainly through reduplication, to indicate property concepts. In addition, some nouns and verbs are employed to signal property notions. The paper has shown that with regard to size, the underived adjective system in Leteh is very much like those in related Kwa languages like Ewe, Ga, Akan and Logba. However, in terms of strategies that these languages apply to denote other property concepts, there are significant differences. For instance, in Leteh, the paper has demonstrated that reduplication is the only derivational process that yields lexemes used for communicating property ideas, whereas in related languages like Akan and Ewe, other derivational processes like suffixation and compounding are attested. It has been observed that whereas the thirteen underived adjectives connote property concepts that border on semantic notions of dimension, color, age and value, some nouns and verbs are used for expressing property concepts of human propensity and physical attributes.

An interesting observation made with respect to morphosyntactic properties of adjectives of value is that they behave differently from all other underived adjectives. For example, adjectives that signal the idea of value do not inflect for number, neither 
do they undergo reduplication. Furthermore, their predicative use is restricted. With respect to reduplication, an explanation that has been offered is that, if it is only adjectives in their plural forms which can undergo reduplication, then it is not surprising that value adjectives cannot be reduplicated. Finally, this paper intimates that the ordering of multiple adjectives seems to be cross-cultural among Kwa languages. However, it will be interesting to research further to come up with other factors that could account for the sequencing.

\section{Abbreviations Used}

COP copula

OC object of comparison

DEF definite article

PL plural

DEM demonstrative

PST past tense

FUT future

REL relativizer

INDEF indefinite article SC standard of comparison

NEGnegation

SG singular

PERF perfect

RELC relative clause

\section{REFERENCES}

Adjei, Francisca, A. 2007. Adjectives in Siyase (Avatime). In Dakubu, M.E., Akanlig-Pare, G., Osam, E.K., Saah, Kofi (eds.) Studies of the Languages of the Volta Basin Vol. 4: 127139.

Akrofi Ansah, Mercy. 2009. Aspects of Lete (Larteh) Grammar. Ph.D. Thesis, The University of Manchester, UK.

Ameka, Felix K. 1991. Ewe: Its grammatical and Illocutionary devices. Ph.D. Thesis, Australian National University, Canberra.

Ameka, Felix. 2003. The Adjective Class in Ewe: Its strata and emergent nature. Unpublished $\mathrm{m}$.

Amfo, N. A., Boateng S., and Otoo Y. 2007. A comparative study of the morphosyntactic properties of adjectives in three Kwa languages. In M.E. Dakubu, G. Akanlig-Pare, E. K. Osam, Kofi Saah (eds.) Studies of the Languages of the Volta Basin Vol. 4: 60-71.

Backhouse, A. E., 1984. Have all the adjectives gone? Lingua 62: 169-186. 
Bybee, Joan L. 1985. Morphology: A Study of the Relation between Meaning and Form. Typological Studies in Language 9. Amsterdam: John Benjamins.

Dakubu, M.E. Kropp. 2003. The Ga Nominal Phrase. Unpublished Manuscript.

Dixon, R.M.W. 1977. Where have all the adjectives gone? Studies in Language 1: 19-80.

Dixon, R.M.W. 1982. Where have all the Adjectives gone? And other essays in Semantics and syntax. Berlin: Mouton.

Dixon, R.M. W. 2004. Adjective classes in typological perspective. In R.M.W. Dixon and Alexandra Y. Aikhenvald (eds.) Adjective Classes. Oxford: O.U.P. Pp. 1-45.

Dixon, R.M.W. 2010. Basic Linguistic Theory. Vol. 2. Grammatical Topics. Oxford: Oxford University Press.

Dorvlo, Kofi. 2009. Does Logba have an adjective class? In M. Matondo, F. McLaughlin, E. Potsdam (eds.) Selected Proceedings of the $38^{\text {th }}$ ACAL. Somerville, MA.

Dryer, Matthew. 2007. Word Order. In Timothy Shopen (ed.). Language Typology and Syntactic Description. Vol. 1. Cambridge: Cambridge University Press.

Ghana Housing and Population Census. 2000. Ghana Statistical Service.

Lewis, M. Paul. (ed.). 2009. Ethnologue: Languages of the World, Sixteenth Edition, Dallas, Tex.: SIL International.

Madugu, Isaac S. George. 1976. Yoruba adjectives have merged with verbs: Or are they just emerging? Journal of West African Languages XVI (2): 9-26.

Omoruyi, Thomas O., 1986. Adjectives and adjectivilization process in Edo. Studies in African Linguistics. 17.3: 283-302.

Osam, E.K. 1999. Adjectives in Akan. Afrika und Übersee, Band 82: 189-211.

Osam, E.K. 2003. Derived adjectives in Akan and Ewe: A comparative analysis. In M. E. Kropp Dakubu and E. K. Osam (eds.) Studies in the Languages of the Volta Basin Vol. 1: 171-179.

Pokuaa, C., E. K. Osam and Kofi K. Saah. 2007. Adjective sequencing in Akan: A preliminary investigation. In M. E. Kropp Dakubu, G. Akanlig-Pare, E. K. Osam and K. K. Saah (eds.). Studies in the Languages of the Volta Basin Vol. 4: Part 1: Nominal Constructions. 
Akrofi-Ansah: Property concepts in Leteh

Schachter, Paul and Timothy Shopen. 2007. Parts-of-speech Systems. In Timothy Shopen (ed.). Language Typology and Syntactic Description Vol. 1: 1-60. Cambridge: Cambridge University Press.

Sproat, Richard and Shih Chilin. 1991. The cross-linguistic distribution of adjective ordering restrictions. In C. Georgopoulos and R. Ishihara (eds.) Interdisciplinary Approaches to Language: Essays in honour of S-Y. Kuroda. Dordrecht: Kluwer Academic Publishers. Pp. 565-593. 